Article

\title{
Nutrient Allocation to Different Compartments of Age-Sequence Larch Plantations in China
}

\author{
Hongxing Wang ${ }^{1}$, Dongsheng Chen ${ }^{1,2}$ and Xiaomei Sun ${ }^{1,2, *}$ \\ 1 Research Institute of Forestry, Chinese Academy of Forestry, Beijing 100091, China \\ 2 State Key Laboratory of Tree Genetics and Breeding, Chinese Academy of Forestry, Beijing 100091, China \\ * Correspondence: xmsun@caf.ac.cn; Tel.: +86-10-6288-9685
}

Received: 30 July 2019; Accepted: 29 August 2019; Published: 3 September 2019

\begin{abstract}
Increased demand for forest-derived biomass has led to more intensive harvesting practices. However, the export of large nutrient quantities with the harvested biomass may lead to the depletion of soil nutrients. Therefore, improved knowledge concerning macronutrient allocation (N, P, K, $\mathrm{Ca}$, and $\mathrm{Mg}$ ) to different components in forests along age sequences is crucial for their sustainable management. In this study, we quantified nutrient allocation to different ecosystem components, including trees, understorey, forest floor, and different soil depths within a chronosequence (6-, 15-, 23-, and 35-year-old) of larch plantations in China. We then assessed the danger of significant nutrient losses from whole tree harvesting (WTH). Nutrient amounts in trees increased with stand age due to an increase in biomass. Stems accounted for $59 \%-72 \%$ of tree biomass and contained $40 \%-50 \%$ of total tree nutrients in the 15- to 35-year-old stands. The forest floor's nutrient quantities increased from the 6- to 23-year-old stands and then decreased in the 35-year-old plantations. Conversely, most soil indicators initially declined from 15- to 23-year-old stands and then increased in the 35-year-old stand. The total nutrient stocks were greatest in the soil $(0-40 \mathrm{~cm})$, which accounted for about $93 \%-99 \%$ of total nutrients in the larch ecosystem. These data indicate that WTH causes nutrient losses about 2.0-2.5 times higher than stem-only harvesting, when thinning 15- or clear-cut harvesting 23- and 35-year-old stands. However, nutrient losses by WTH have little effect on the soil nutrient pools. Prolonging the crop cycle of larch plantations may be beneficial to improve nutrient return through litterfall and allow available soil nutrients to recover.
\end{abstract}

Keywords: Larix kaempferi; stand age; nutrient allocation; nutrient stocks; tree harvesting system

\section{Introduction}

The use of biomass-based fuels for energy is increasing rapidly due to the need for reduced greenhouse gas emissions [1]. One method for obtaining bioenergy sources is the intensive forest management whole-tree harvest (WTH) method, in which the stems, logging residues, and eventually stumps removed from the site [2] may become an alternative to conventional stem-only harvest $(\mathrm{SOH})$, in which only the stems are harvested while logging residues and stumps remain on-site [3-5]. However, intensive harvest treatments may cause further nutrient losses due to the removal of nutrient-rich components from the site $[6,7]$. This has raised concerns on whether more nutrient losses lead to further soil nutrient depletion and lower site productivity [8,9].

In considering this phenomenon, numerous studies have reported on the effects of nutrient losses in soil due to WTH or removal of the understory and forest floor [10-13]. Phillips and Watmough [12] found a mild decrease in the available soil stocks of $\mathrm{K}$ and Ca by generating a detailed nutrient budget before and after stem-only selection cutting in sugar maple stands in Ontario. Duchesne and Houle [14] suggested that WTH of boreal forests in Quebec led to substantial net losses of potassium (K) and to a lesser extent calcium (Ca), but not magnesium (Mg). Menegale et al. [15] observed a reduction 
in organic $\mathrm{C}$, total $\mathrm{N}$, available $\mathrm{P}$ and $\mathrm{S}$ stocks in the whole tree harvest treatment in a Eucalyptus plantation, especially at $0-40 \mathrm{~cm}$. However, some studies observed the same result in sites with high soil nutrient stocks even though whole trees may be harvested without substantial reductions in ecosystem nutrient pools [16-18]. The net annual soil nutrient losses were a very small proportion of the total soil nutrient stores $(<0.8,<0.2,<0.02,<0.2$, and $<0.04 \%$ of the soil pools of total nitrogen $(\mathrm{N})$, phosphorus (P), K, Ca, and $\mathrm{Mg}$, respectively) in different-aged plantations of Chinese fir [19]. No negative consequences were found on forest productivity or soil properties in the mineral soil layer and forest floor due to intensive biomass utilization 38 years after harvesting [20]. From the above research, the inconsistent results were found about how nutrient removal via biomass harvesting affects soil properties, and these differences may be related to tree species, site factors, and management measures. The effects of intensive harvest management on soil nutrient status may depend on how much of the total and available quantities of nutrients are harvested in the system $[9,21]$. Hence, information regarding nutrient allocation in different compartments of diverse forest ecosystems is needed to reliably judge the sustainability of more intensive harvest regimes [22].

Larches (Larix spp.) are an important component in many cold-temperate and boreal forests in the Northern Hemisphere [23], and the dominant timber species in plantation forests in China [24,25]. Larch plantations provide a high proportion of the timber supply, and they now cover $3.14 \times 10^{6}$ ha in China (Chinese Ministry of Forestry, 2014). Many fast-growing plantations, such as those of Chinese fir and larches, are generally managed by a system that involves site preparation, clear-cutting, and successive rotation [26]. Moreover, larch plantations are frequently subjected to various harvesting regimes (e.g., SOH and WTH) [27]. Thus, it is essential to understand nutrient allocation among different compartments of the larch ecosystem in order to analyze nutrient losses as a consequence of harvesting and to establish an optimal harvesting regime. Although few studies have reported on nutrient accumulation in larch plantations, these studies mainly focus on changes in nutrient accumulation in vegetation and the forest floor [28-30], without considering the ideal soil nutrient storage (pool size on a volumetric basis) for estimating nutrient balances [26].

In this study, nutrient allocation ( $, \mathrm{P}, \mathrm{K}, \mathrm{Ca}$, and $\mathrm{Mg}$ ) was evaluated in different compartments of the larch ecosystem, including the trees, understory, and forest floor, as well as the rarely reported soil layer. The objectives of this study were to explore the following questions: (1) what are the conditions of nutrient allocation in the trees, understory, forest floor, and soil in age-sequence larch plantations; (2) how significant are the effects on nutrient removal due to harvesting ecosystem nutrient pools; and (3) what is the optimum harvesting method in larch plantations required to maximize biomass harvesting while minimizing nutrient loss.

\section{Materials and Methods}

\subsection{Study Site}

This study was conducted in a pure Larix kaempferi (Lamb.) Carr. plantation in the mountainous region of Gansu Province, northwest China $\left(34^{\circ} 13^{\prime}\right.$ N, $105^{\circ} 48^{\prime}$ E, and elevation 1428-1790 m above sea level). This region has a continental monsoon climate with a mean annual temperature of $7-12{ }^{\circ} \mathrm{C}$, and a mean annual frost-free period of about 180 days each year. The annual precipitation ranges from 460 to $800 \mathrm{~mm}$, with about $80 \%$ precipitation concentrated throughout June to August. Four stands of 6-, 15-, 23-, and 35-year-old larch plantations were selected, and each was in its first crop cycle. A total of 24 plots $(20 \mathrm{~m} \times 30 \mathrm{~m})$ were selected with similar climate and micro-environmental conditions. All stands were developed by replacing secondary forests, except the 6-year-old plantation, which was developed by replacing shrub forests. The 15-, 23-, and 35-year-old plantations had been thinned under the same standard practice. The soils of the four stands were cinnamon soil according to the national standards of China (China soil classification and code GB/T 17296-2009). The dominant species in the understory in all stands are Corylus heterophylla Fisch., Euonymus phellomanus Loes., Artemisia annua 
Linn., Artemisia eriopoda Bge., and Melilotus officinalis (Linn.) Pall. The main characteristics of stands are listed in Table 1.

Table 1. The stand characteristics of different age larch plantations.

\begin{tabular}{ccccccccc}
\hline Ages & $\begin{array}{c}\text { Plots } \\
\text { Number }\end{array}$ & $\begin{array}{c}\text { DBH } \\
(\mathbf{c m})\end{array}$ & $\begin{array}{c}\text { Tree } \\
\text { Height }(\mathbf{m})\end{array}$ & $\begin{array}{c}\text { Density } \\
\left(\mathbf{N ~ h a} \mathbf{- 1}^{-1}\right.\end{array}$ & $\begin{array}{c}\text { Elevation } \\
(\mathbf{m})\end{array}$ & $\begin{array}{c}\text { Soil Depth } \\
\mathbf{( \mathbf { c m } )}\end{array}$ & $\begin{array}{c}\text { Slope } \\
(\mathbf{(})\end{array}$ & Year (s) Thinned \\
\hline 6-year & 6 & $3.3 \pm 0.4$ & $3.8 \pm 0.3$ & $3092 \pm 252$ & 1552 & $63.9 \pm 3.8$ & 23 & - \\
15-year & 6 & $11.1 \pm 1.0$ & $11.5 \pm 0.6$ & $2316 \pm 150$ & 1786 & $70.0 \pm 2.3$ & 19 & 2008 \\
23-year & 6 & $17.5 \pm 1.3$ & $17.1 \pm 1.6$ & $697 \pm 68$ & 1580 & $73.0 \pm 3.2$ & 19 & $1997,2003,2008$ \\
35-year & 6 & $21.4 \pm 1.8$ & $18.8 \pm 1.1$ & $558 \pm 65$ & 1584 & $63.6 \pm 3.2$ & 26 & $1987,1992,1999,2004$ \\
\hline
\end{tabular}

\subsection{Biomass Determination and Sample Extraction}

In each plot, all trees with a diameter at breast height $(\mathrm{DBH}) \geq 5 \mathrm{~cm}$ were measured for $\mathrm{DBH}$ and height in September 2009. All trees were divided into three size classes (dominant, co-dominant, and suppressed) in each plot based individual DBH. A total of 54 model trees were felled, the stems were cut into $1 \mathrm{~m}$ sections, and a stem disc ( $2 \mathrm{~cm}$ wide) was taken from each section as a stem subsample. The live crown was divided into three layers (upper, middle, and lower), and two model branches, which had their leaves completely clipped, were selected randomly from each layer [31]. All branches in each sample tree were cut from the stem and all roots were excavated to a depth of $0.65 \mathrm{~m}$ (maximum rooting depth). The fresh weight of each component (stemwood, roots, branches, bark, and needles) for each tree was measured in the field. The stand biomass was determined by the average standard tree method.

The understory biomass was directly measured by harvesting and weighing all plant tissue collected from five randomly selected plots $(1 \mathrm{~m} \times 1 \mathrm{~m})$ for the herb layer and one plot $(5 \mathrm{~m} \times 5 \mathrm{~m})$ for the shrub layer in each stand. The forest floor was randomly collected from nine quadrates $(1 \mathrm{~m} \times 1 \mathrm{~m})$ in each plot and sorted into branches, foliage, and other material (including flowers, fruits, and bark). All samples were weighed fresh, and sub-samples were taken to the laboratory and oven-dried at $80^{\circ} \mathrm{C}$ to a constant weight for moisture determination. Three dried subsamples from each component were taken to determine nutrient concentrations. Each component biomass was calculated by multiplying the total fresh weight by the dry weight rate of each component. Nutrient stocks in different components were obtained by multiplying the nutrient concentration by its respective biomass.

\subsection{Soil Sampling}

Nine soil cores of each soil layer $(0-10,10-20$, and 20-40 cm) were collected in an "S" shape from each plot after removing the litter layer and then combined into two subsamples in one plot: one was oven dried to determine soil moisture, and the other was air-dried and sifted through a sieve with 2 $\mathrm{mm}$ mesh to determine soil chemical properties. The soil bulk density was determined by collecting samples involumetric rings $\left(100 \mathrm{~cm}^{3}\right)$, removing stones ( $>2 \mathrm{~mm}$ diameter), and drying to a constant weight before re-weighing. Three pits in each plot were chosen, and the cylinder was pushed into the vertical face of soil pits. Soil nutrient stocks per soil layer were estimated by multiplying nutrient concentrations with the corresponding weight of the $<2 \mathrm{~mm}$ soil fraction [32]. The soil nutrient stocks were calculated by multiplying the mean nutrient in each layer by the corresponding mean soil bulk density [19].

\subsection{Chemical Analysis}

Plant materials were ground by a mechanical mill before passing through a $60 \mathrm{~mm}$ mesh sieve. The N concentration was measured using an elemental analyzer (2400 II CHNS; Perkin-Elmer, Boston, MA, USA), while $\mathrm{P}, \mathrm{K}, \mathrm{Ca}$, and $\mathrm{Mg}$ were extracted via microwave nitric acid digestion and measured by inductively coupled plasma spectroscopy (Thermo Scientific, West Palm Beach, FL, USA). For soil samples, pH was determined using a glass electrode with a 1:2.5 soil-water slurry. Soil organic mass (SOM) was determined using heated dichromate titration, and total nitrogen (TN) 
was quantified according to the Kjeldahl procedure. Total phosphorus (TP) and total potassium (TK) were measured using the $\mathrm{NaOH}$ fusion-Mo-Sb anti-spectrophotometric method and the $\mathrm{NaOH}$ fusion-flame spectrometric method, respectively. Total soil $\mathrm{Ca}$ and $\mathrm{Mg}$ were determined using the acid fusion-atomic absorbance spectrophotometric method. Available nitrogen (AN) was determined by the $\mathrm{NaOH}$-hydrolyzing $\mathrm{NH}_{3}$-diffusing $\mathrm{H}_{3} \mathrm{BO}_{3}$-absorption method. Available phosphorus (AP) was determined using the molybdate blue colorimetric method after extraction with sodium bicarbonate. Available potassium (AK) was extracted by $1 \mathrm{~N} \mathrm{NH}_{4} \mathrm{OAc}$ solution and measured by a flame photometer. All plant materials were analyzed in the State Key Laboratory of Vegetation and Environmental Change of the Institute of Botany, Chinese Academy of Sciences, and soil samples were examined at the Northeast Institute of Geography and Agroecology, Chinese Academy of Sciences.

\subsection{Statistical Analysis}

All statistical analyses were conducted using the Software Statistical Package for Windows (SPSS 17.0, Chicago, IL, USA). Two-way ANOVA was used to check the influence of stand age, soil depth, and their interaction on soil parameters. Moreover, one-way analysis of variance (ANOVA) followed by a post hoc least significant differences (LSD) test was applied to determine the effect of stand age or soil depth on soil parameters ( $\mathrm{pH}, \mathrm{SOM}, \mathrm{TN}, \mathrm{AN}, \mathrm{TP}, \mathrm{AP}, \mathrm{TK}, \mathrm{AK}, \mathrm{Ca}$, and $\mathrm{Mg}$ ). Before performing ANOVA, data normality and the homogeneity of variances were tested. Statistically significant differences were designated at $p<0.05$.

\section{Results}

\subsection{Soil Chemical Properties}

Soil properties (SOM, TN, AN, AP, and AK) were significantly influenced by stand age, soil depth, and their interaction (Table 2). These parameters decreased with increasing soil depth in the 15-, 23-, and 35-year-old larch plantations. However, in the 6-year-old plantation, these were lower in the layer at $0-10 \mathrm{~cm}$ than at $10-20 \mathrm{~cm}$. This difference may be mainly explained by differences in land-use history and soil preparation before afforestation. Moreover, SOM, TN, AN, TP, AP, and AK concentrations initially declined from the 15- to 23-year-old stands and then increased. In general, SOM, TN, AN, $\mathrm{TP}, \mathrm{AP}$, and $\mathrm{AK}$ concentrations were significantly higher in the 35-year-old stand than in the other three stands (Figure 1). In addition, stand age significantly influenced soil $\mathrm{pH}$, which was significantly higher in the 6-year-old plantation than in the other three stands. Both the effect of stand age and soil depth were not significant on soil TK, Ca, and Mg concentrations.

Table 2. Two-way ANOVA results of stand age and soil depth influences on different soil parameters.

\begin{tabular}{cccccccc}
\hline \multirow{2}{*}{ No. } & Parameter & \multicolumn{2}{c}{ Stand Age } & \multicolumn{2}{c}{ Soil Depth } & \multicolumn{2}{c}{ Interaction } \\
\cline { 3 - 7 } & & $\boldsymbol{F}$ & $\boldsymbol{p}$ & $\boldsymbol{F}$ & $\boldsymbol{p}$ & $\boldsymbol{F}$ & $\boldsymbol{p}$ \\
\hline 1 & $\mathrm{pH}$ & $\mathbf{2 2 . 6 3}$ & $\mathbf{0 . 0 0}$ & 0.89 & 0.42 & 0.27 & 0.95 \\
2 & $\mathrm{SOM}$ & $\mathbf{8 8 . 3 4}$ & $\mathbf{0 . 0 0}$ & $\mathbf{4 8 . 0 3}$ & $\mathbf{0 . 0 0}$ & $\mathbf{1 1 . 0 4}$ & $\mathbf{0 . 0 0}$ \\
3 & $\mathrm{TN}$ & $\mathbf{2 9 . 8 6}$ & $\mathbf{0 . 0 0}$ & $\mathbf{7 4 . 1 5}$ & $\mathbf{0 . 0 0}$ & $\mathbf{5 . 4 1}$ & $\mathbf{0 . 0 0}$ \\
4 & $\mathrm{AN}$ & $\mathbf{1 0 6 . 9 8}$ & $\mathbf{0 . 0 0}$ & $\mathbf{2 7 . 1 1}$ & $\mathbf{0 . 0 0}$ & $\mathbf{7 . 2 3}$ & $\mathbf{0 . 0 0}$ \\
5 & $\mathrm{TP}$ & $\mathbf{1 5 . 9 1}$ & $\mathbf{0 . 0 0}$ & 0.62 & 0.54 & 1.10 & 0.17 \\
6 & $\mathrm{AP}$ & $\mathbf{3 6 . 8 1}$ & $\mathbf{0 . 0 0}$ & $\mathbf{1 1 4 . 0 3}$ & $\mathbf{0 . 0 0}$ & $\mathbf{1 4 . 0 7}$ & $\mathbf{0 . 0 0}$ \\
7 & $\mathrm{TK}$ & 2.41 & 0.06 & 0.43 & 0.65 & 0.06 & 1.00 \\
8 & $\mathrm{AK}$ & $\mathbf{8 . 1 3}$ & $\mathbf{0 . 0 0}$ & $\mathbf{1 7 . 2 5}$ & $\mathbf{0 . 0 0}$ & $\mathbf{5 . 6 8}$ & $\mathbf{0 . 0 0}$ \\
9 & $\mathrm{Ca}$ & 0.81 & 0.50 & 0.01 & 0.99 & 0.29 & 0.94 \\
10 & $\mathrm{Mg}$ & 0.46 & 0.71 & 0.36 & 0.70 & 0.47 & 0.83 \\
\hline
\end{tabular}

Bold italics in this table indicates that the differences are statistically significant at $p<0.05$. 

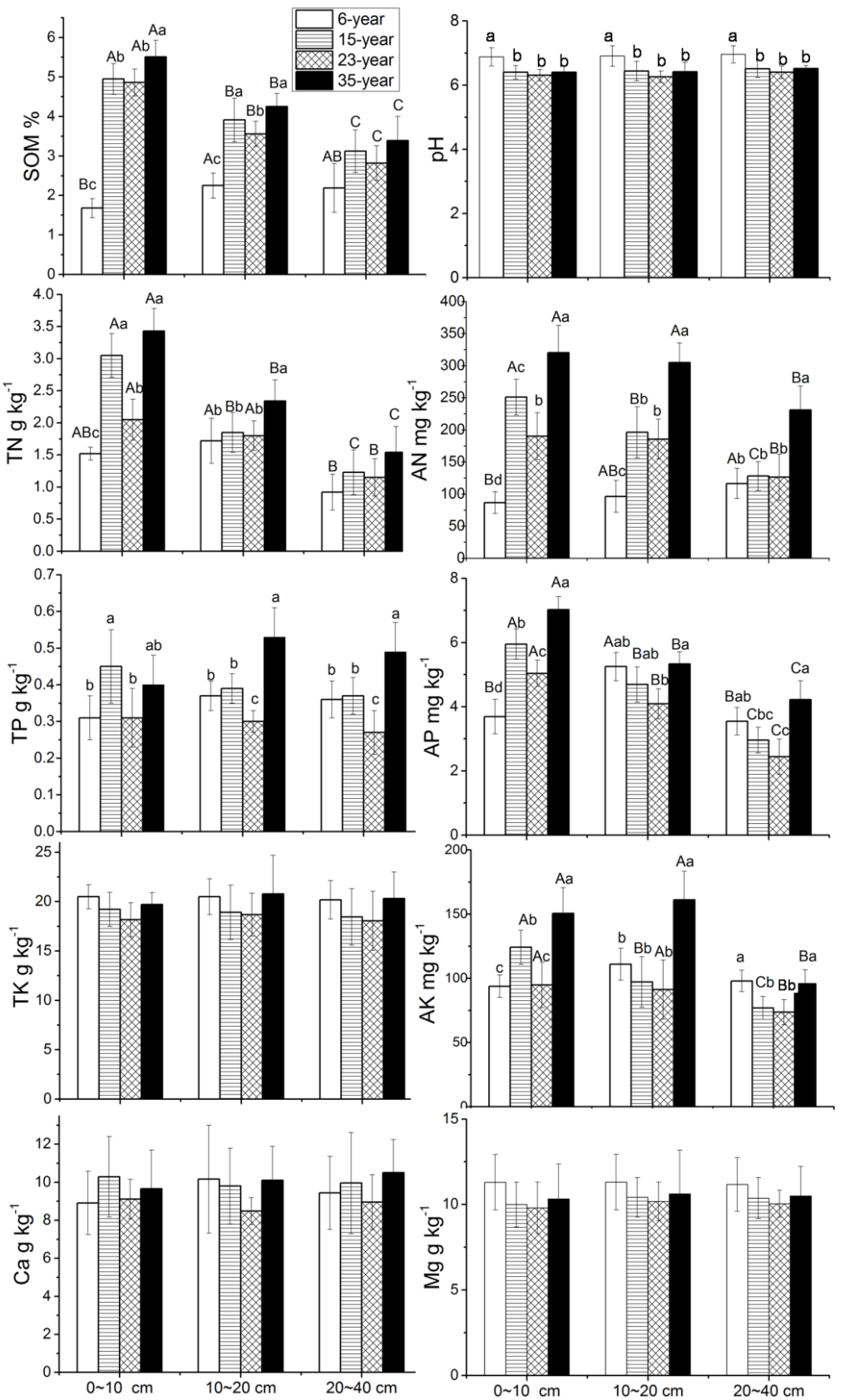

Figure 1. Soil chemical properties in four ages larch plantations. Different lower-case letters indicate significant differences in the same soil depth among different-aged plantations $(p<0.05)$. Different upper-case letters indicate significant differences in the same stand age among different soil depths $(p<0.05)$. No letters indicates lack of significant differences. Error bars indicate standard deviation.

\subsection{Nutrient Concentrations}

Among the different tree components, nutrient concentrations were highest in needles; intermediate in branches, roots, and bark; and lowest in stemwood (Figure 2). Nutrient concentrations in needles, roots, and branches followed the order of $\mathrm{N}>\mathrm{K}>\mathrm{Ca}>\mathrm{P}>\mathrm{Mg}$, while concentrations in stemwood and bark ranked as $\mathrm{Ca}>\mathrm{N}>\mathrm{K}>\mathrm{P}>\mathrm{Mg}$. All nutrient concentrations in stemwood decreased with stand age, except for $\mathrm{Ca}$ and $\mathrm{Mg}$, which increased. $\mathrm{P}$ and $\mathrm{Ca}$ concentrations in needles declined with age. In the understory, nutrient concentrations were highest in the shrub leaves and above-grass, intermediate in shrub roots and below-grass, and lowest in the shrub branches (Figure 2). All nutrient concentrations were higher in understory components than in all tree components (except 
needles). The $\mathrm{N}$ concentration was similar between shrub leaves (24.3-29.1 $\mathrm{g} \mathrm{kg}^{-1}$ ) and larch needles (18.5-24.6 $\mathrm{g} \mathrm{kg}^{-1}$ ). P and Mg were highest in below-grass, with 2 or 3-fold higher concentrations than in larch needles. K concentrations were $17.6-27.9 \mathrm{~g} \mathrm{~kg}^{-1}$ in above-grass-the highest among all components and 3-fold more than that in larch needles. Ca concentrations reached 14.4-19.5 g $\mathrm{kg}^{-1}$ in shrub leaves, approximately twice that in larch needles. In the forest floor, $\mathrm{N}, \mathrm{Ca}$, and $\mathrm{Mg}$ concentrations increased with stand age, whereas $\mathrm{K}$ and $\mathrm{P}$ concentrations decreased. The forest floor had the highest $\mathrm{Ca}$ concentration at 17.0-19.4 $\mathrm{g} \mathrm{kg}^{-1}$, medium-high $\mathrm{N}$ concentrations, and low concentrations of $\mathrm{Mg}, \mathrm{P}$, and especially $\mathrm{K}$.

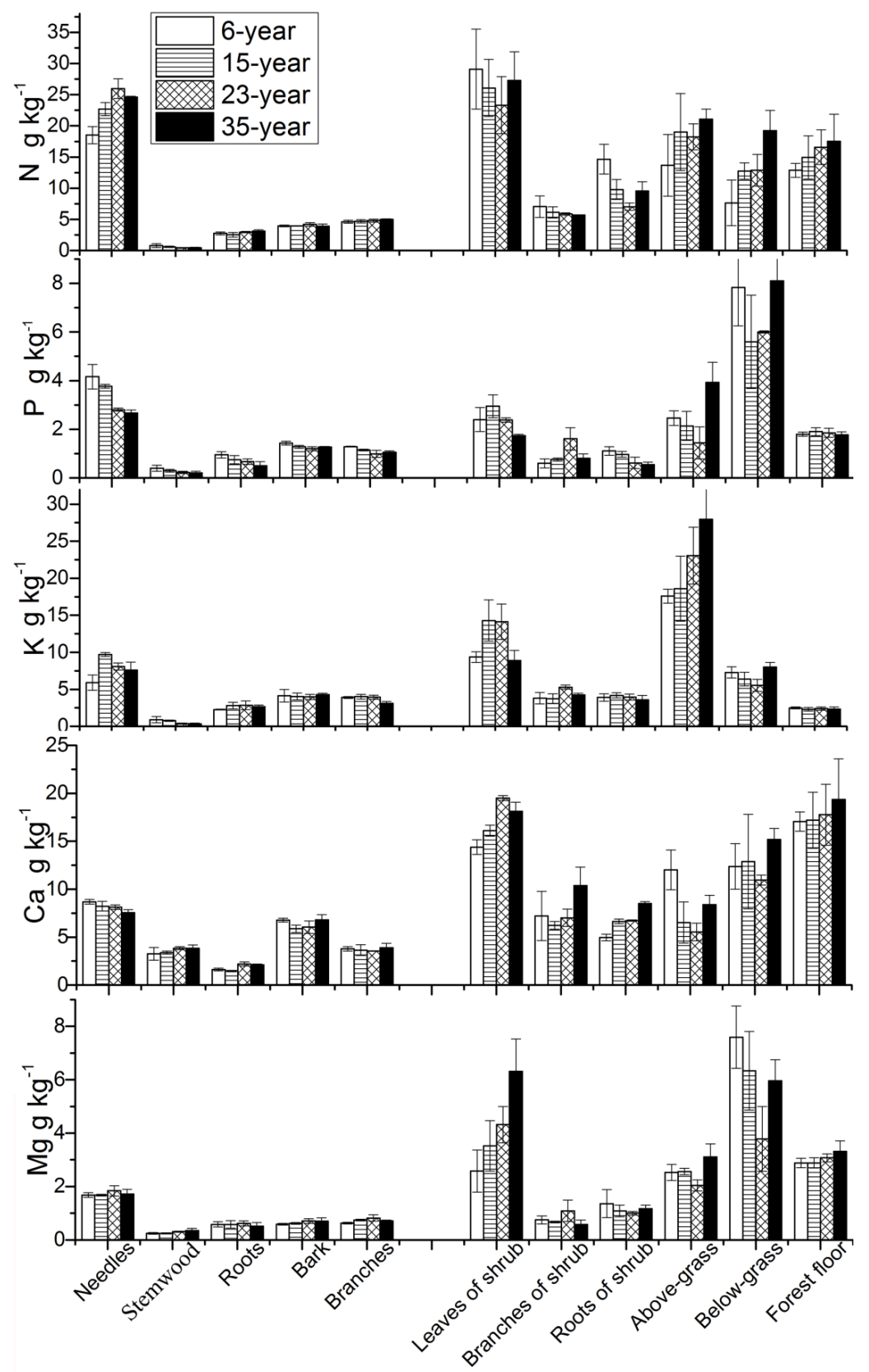

Figure 2. Nutrient concentrations in different components of an age-sequence of larch stands. Error bars indicate standard deviations.

\subsection{Nutrient Allocation}

The pattern of biomass allocation among various tree components was the same in the 15-, 23-, and 35-year-old plantations (stemwood $>$ roots $>$ branches $>$ bark $>$ needles), but not in the 6-year-old 
stand (stemwood $>$ roots $>$ branches $>$ needles $>$ bark) (Table 3). Nutrient accumulations in trees increased with age due to an increase in biomass. Regarding the proportion of tree biomass, stemwood was greatest at $33.7 \%-54.8 \%$, but nutrient quantities were only $12.1 \%-33.2 \%$. Needles contributed the least to total tree biomass, accounting for only $4.5 \%, 3.7 \%$, and $2.3 \%$ of tree biomass in the 15-, 23-, and 35-year-old stands, respectively, while total nutrient amounts in needles accounted for $21.5 \%, 19.1 \%$, and $12.2 \%$, respectively. In the 6-year-old plantation, $\mathrm{N}$ accumulation in trees was highest, accounting for $37.7 \%$, followed by $\mathrm{Ca}, \mathrm{K}, \mathrm{P}$, and $\mathrm{Mg}$. However, in the remaining three stands, Ca accumulation was the most abundant, ranging from $32.9 \%$ to $44.3 \%$, followed by $\mathrm{N}, \mathrm{K}, \mathrm{P}$, and $\mathrm{Mg}$.

Table 3. Biomass and nutrient allocation to different tree components of the four ages of larch stands.

\begin{tabular}{|c|c|c|c|c|c|c|c|c|c|c|}
\hline \multirow[b]{2}{*}{ Ages } & \multirow[b]{2}{*}{ Components } & \multicolumn{2}{|c|}{ Biomass } & \multicolumn{7}{|c|}{ Nutrient Stocks $\left(\mathrm{kg} \mathrm{ha}^{-1}\right)$} \\
\hline & & $\begin{array}{c}(\mathrm{Mg} \\
\left.\mathrm{ha}^{-1}\right)\end{array}$ & $\begin{array}{c}\text { Percentage } \\
(\%)\end{array}$ & $\mathbf{N}$ & $\mathbf{P}$ & $\mathbf{K}$ & $\mathrm{Ca}$ & $\mathrm{Mg}$ & Total & $\begin{array}{c}\text { Percentage } \\
(\%)\end{array}$ \\
\hline \multirow[t]{7}{*}{ 6-year } & Needles & 1.2 & 14.8 & 24.6 & 4.6 & 6.4 & 10.5 & 2.0 & 48.1 & 41.6 \\
\hline & Stemwood & 2.7 & 33.3 & 2.8 & 1.2 & 2.5 & 6.8 & 0.7 & 13.9 & 12.1 \\
\hline & Bark & 0.8 & 9.9 & 3.2 & 1.1 & 4.0 & 5.7 & 0.5 & 14.5 & 12.6 \\
\hline & Roots & 1.4 & 17.3 & 3.4 & 1.3 & 3.2 & 2.0 & 0.8 & 10.7 & 9.3 \\
\hline & Branches & 2.0 & 24.7 & 9.4 & 2.5 & 7.5 & 7.4 & 1.2 & 28.0 & 24.3 \\
\hline & Total & 8.1 & 100 & 43.4 & 10.6 & 23.7 & 32.4 & 5.2 & 115.2 & 100 \\
\hline & Percentage (\%) & - & - & 37.7 & 9.2 & 20.5 & 28.1 & 4.5 & 100 & - \\
\hline \multirow[t]{7}{*}{ 15-year } & Needles & 2.9 & 4.5 & 69.3 & 11.0 & 28.4 & 25.4 & 4.9 & 139.0 & 21.5 \\
\hline & Stemwood & 32.0 & 49.6 & 20.2 & 11.1 & 27.9 & 103.0 & 8.9 & 171.1 & 26.4 \\
\hline & Bark & 5.7 & 8.8 & 22.7 & 7.3 & 23.0 & 34.0 & 3.6 & 90.7 & 14 \\
\hline & Roots & 14.4 & 22.3 & 34.6 & 13.1 & 41.4 & 20.4 & 7.5 & 117.0 & 18.1 \\
\hline & Branches & 9.5 & 14.7 & 44.8 & 10.8 & 37.3 & 29.8 & 6.8 & 129.4 & 20 \\
\hline & Total & 64.5 & 100 & 191.5 & 53.2 & 157.9 & 212.7 & 31.7 & 647.0 & 100 \\
\hline & Percentage (\%) & - & - & 29.6 & 8.2 & 24.4 & 32.9 & 4.9 & 100 & - \\
\hline \multirow[t]{7}{*}{ 23-year } & Needles & 3.1 & 3.6 & 86.7 & 8.8 & 26.2 & 27.1 & 5.2 & 154.0 & 19.1 \\
\hline & Stemwood & 53.6 & 62.7 & 24.7 & 11.2 & 25.7 & 196.7 & 15.5 & 273.8 & 33.9 \\
\hline & Bark & 7.9 & 9.2 & 35.8 & 9.9 & 34.7 & 42.0 & 5.8 & 128.1 & 15.8 \\
\hline & Roots & 12.5 & 14.6 & 38.7 & 9.9 & 41.5 & 30.6 & 9.1 & 129.6 & 16 \\
\hline & Branches & 8.4 & 9.8 & 42.6 & 8.3 & 35.4 & 30.0 & 6.6 & 123.0 & 15.2 \\
\hline & Total & 85.5 & 100 & 228.5 & 48.0 & 163.5 & 326.4 & 42.1 & 808.5 & 100 \\
\hline & Percentage (\%) & - & - & 28.3 & 5.9 & 20.2 & 40.4 & 5.2 & 100 & - \\
\hline \multirow{7}{*}{ 35-year } & Needles & 3.0 & 2.6 & 67.9 & 8.5 & 21.8 & 24.2 & 5.1 & 127.5 & 12.2 \\
\hline & Stemwood & 63.6 & 54.6 & 22.6 & 13.9 & 20.4 & 261.3 & 27.8 & 346.1 & 33.2 \\
\hline & Bark & 8.6 & 7.4 & 32.1 & 10.7 & 38.0 & 62.3 & 7.2 & 150.3 & 14.4 \\
\hline & Roots & 31.0 & 26.6 & 103.8 & 20.3 & 57.7 & 64.8 & 18.6 & 265.2 & 25.5 \\
\hline & Branches & 10.3 & 8.4 & 51.8 & 11.5 & 33.1 & 48.3 & 7.6 & 152.3 & 14.6 \\
\hline & Total & 116.5 & 100 & 278.2 & 65.0 & 171.0 & 460.9 & 66.3 & 1041.4 & 100 \\
\hline & Percentage (\%) & - & - & 26.7 & 6.2 & 16.4 & 44.3 & 6.4 & 100 & - \\
\hline
\end{tabular}

Percentage within the same line are the proportion of various nutrient elements accounting for the total amount in the same age plantation. Percentages within the same column are the proportion of various tree components accounting for the total amount in the same age plantation.

In the understory of the 6-year-old stand, the nutrient quantity was $467.3 \mathrm{~kg} \mathrm{ha}^{-1}$, which was about three times that in trees. In the remaining three stands, the understory nutrient stocks ranged from 214.2 to $241.3 \mathrm{~kg} \mathrm{ha}^{-1}$, which approximately accounted for $14 \%-20 \%$ of the total vegetation and forest floor nutrient stocks (Table 4).

The nutrient stocks of the forest floor accumulated $13 \%-35 \%$ of the total vegetation in different-aged stands. These stocks increased from the 6- to 23-year-old stand, and then decreased in the 35-year-old stand. In all stands, the forest floor accumulated the highest proportion of $\mathrm{Ca}$, followed by $\mathrm{N}, \mathrm{Mg}$, $\mathrm{K}$, and P (Table 4).

Compared to the trees, understory, and forest floor, the soil nutrient pools were very high. $\mathrm{N}$ and P stocks in soil accounted for around $93 \%$ of each respective total nutrient in the larch ecosystem, while $\mathrm{K}, \mathrm{Ca}$, and $\mathrm{Mg}$ stocks in soil accounted for about $99 \%$ (Table 4). 
Table 4. Biomass and nutrient allocation to different compartments of the larch ecosystem.

\begin{tabular}{|c|c|c|c|c|c|c|c|c|c|}
\hline \multirow[b]{2}{*}{ Ages } & \multirow[b]{2}{*}{ Compartments } & \multicolumn{2}{|c|}{ Biomass } & \multicolumn{6}{|c|}{ Nutrient Stocks ( $\left.\mathrm{kg} \mathrm{ha}^{-1}\right)$} \\
\hline & & $\begin{array}{l}(\mathrm{Mg} \\
\left.\mathrm{ha}^{-1}\right)\end{array}$ & $\begin{array}{l}\text { Percentage } \\
(\%)\end{array}$ & $\mathbf{N}$ & $\mathbf{P}$ & $\mathbf{K}$ & $\mathrm{Ca}$ & Mg & Total \\
\hline \multirow[t]{4}{*}{ 6-year } & Tree & 8.1 & 34.8 & 43.4 & 10.6 & 23.7 & 32.4 & 5.2 & 115.3 \\
\hline & Understory & 12.8 & 54.9 & 158.2 & 36.9 & 109.9 & 124.6 & 37.7 & 467.3 \\
\hline & Forest floor & 2.4 & 10.3 & 30.6 & 4.3 & 5.9 & 40.5 & 6.9 & 88.1 \\
\hline & Soil & - & - & 4570 & 1560 & 84,470 & 36,980 & 42,790 & 170,370 \\
\hline \multirow[t]{4}{*}{ 15-year } & Tree & 64.5 & 78.0 & 191.5 & 53.2 & 157.9 & 212.7 & 31.7 & 647.1 \\
\hline & Understory & 9.9 & 12.0 & 92.8 & 12.2 & 50.6 & 72.8 & 12.9 & 241.3 \\
\hline & Forest floor & 8.3 & 10.0 & 120.8 & 15.7 & 19.0 & 140.1 & 23.8 & 319.3 \\
\hline & Soil & - & - & 5690 & 1690 & 87,870 & 35,100 & 42,610 & 172,960 \\
\hline \multirow[t]{4}{*}{ 23-year } & Tree & 85.5 & 81.0 & 228.5 & 48.0 & 163.5 & 326.4 & 42.1 & 808.5 \\
\hline & Understory & 7.7 & 7.3 & 84.6 & 12.2 & 49.0 & 57.6 & 10.7 & 214.2 \\
\hline & Forest floor & 12.3 & 11.7 & 201.1 & 22.7 & 29.3 & 215.9 & 37.6 & 506.5 \\
\hline & Soil & - & - & 6970 & 1590 & 84,990 & 34,670 & 41,430 & 169,650 \\
\hline \multirow[t]{4}{*}{ 35-year } & Tree & 116.5 & 90.2 & 278.2 & 65.0 & 171.0 & 460.9 & 66.4 & 1041.5 \\
\hline & Understory & 6.9 & 5.3 & 81.4 & 17.4 & 44.2 & 76.5 & 14.3 & 233.8 \\
\hline & Forest floor & 5.8 & 4.5 & 117.3 & 11.9 & 15.7 & 130.1 & 22.4 & 297.4 \\
\hline & Soil & - & - & 7720 & 1790 & 85,560 & 37,340 & 40,400 & 172,810 \\
\hline
\end{tabular}

\section{Discussion}

\subsection{Nutrient Concentrations}

Among the tree components, nutrient concentrations were generally highest in the needles; intermediate in branches, bark, or roots; and lowest in stemwood, a tendency that is widely documented in previous studies [33-35]. In this study, N, P, and K concentrations in stemwood decreased with age. This is attributed to nutrient translocation and the dilution effect [36]. Conversely, Ca concentration in stemwood increased with age, which is likely due to the fact that $\mathrm{Ca}$ is the least mobile of the macronutrients and accumulates in structural tissues such as stems [37]. $\mathrm{N}$ concentrations were higher in larch needles $\left(22 \mathrm{~g} \mathrm{~kg}^{-1}\right)$ than in radiata pine $\left(13.4 \mathrm{~g} \mathrm{~kg}^{-1}\right)$ and Chinese fir $\left(13.1 \mathrm{~g} \mathrm{~kg}^{-1}\right)$ needles $[38,39]$. However, as a deciduous needleleaf species, larches can retranslocate approximately $60 \%$ of the nitrogen from their senescing needles [40]. $\mathrm{N}$ concentrations in stemwood decreased with age from 0.8 for 6- to $0.43 \mathrm{~g} \mathrm{~kg}^{-1}$ for 35-year-old stand, which is in agreement with the findings by Zhao et al. [29]. In their study, the authors report a reduction in $\mathrm{N}$ concentrations in stemwood from 0.8 to $0.6 \mathrm{~g} \mathrm{~kg}^{-1}$ as age increased in age-sequence Larix olgensis Henry. plantations. Moreover, these results were much lower than those presented by Yang et al. [27], who reported that $\mathrm{N}$ concentrations in stemwood increased with age, reaching up to $2.5,3.7,5.0$, and $5.1 \mathrm{~g} \mathrm{~kg}^{-1}$ in 10-, 21-, 34-, and 55-year-old larch plantations, respectively. These data can be argued for two reasons. First, in almost all previous studies, $\mathrm{N}$ concentrations in stemwood were widely believed to decrease with age [18,29,36-38]. Second, the concentrations reported in most previous literature never reached $5 \mathrm{~g} \mathrm{~kg}^{-1}$, even in broadleaf species with higher nutrient requirements [12,13,41-45]. Furthermore, it is worth noting that the forest floor had the highest Ca concentrations, which increased with age. Hernández et al. [46] found that Ca concentrations tended to increase over 24 months of decomposition. This may be attributed to the litterfall decomposition process, during which $\mathrm{Ca}$ is most slowly depleted due to the structural compounds in litter, and only a small proportion is present as free $\mathrm{Ca}^{+2}[47]$.

\subsection{Nutrient Allocation to Different Compartments}

Stemwood represented the highest proportion of tree biomass $(49.6 \%-54.6 \%)$ and a relatively lower percentage of tree nutrients (26.4\%-33.9\%; Figure 3a), which is consistent with many studies for other tree species $[38,48]$. Furthermore, the tree biomass accounted for $79.5 \%-89.5 \%$ of the total vegetation and forest floor biomass, which only contained $53.6 \%-66.2 \%$ of the total vegetation and forest floor 
nutrient amounts in the 15-, 23-, and 35-year-old plantations (Figure 3b). Therefore, larch stems only accounted for a quarter of the total vegetation and forest floor nutrients. The understory contained $27.2 \%, 20.9 \%$, and $18.3 \%$ of the total vegetation nutrient quantities in the 15-, 23-, and 35-year-old stands, respectively, while it accounted for only 13.2, 8.2, and 5.6\% of the vegetation biomass, accordingly. Although they formed a relatively small portion of the total biomass, the understory and forest floor were significant components of nutrient cycling $[49,50]$.
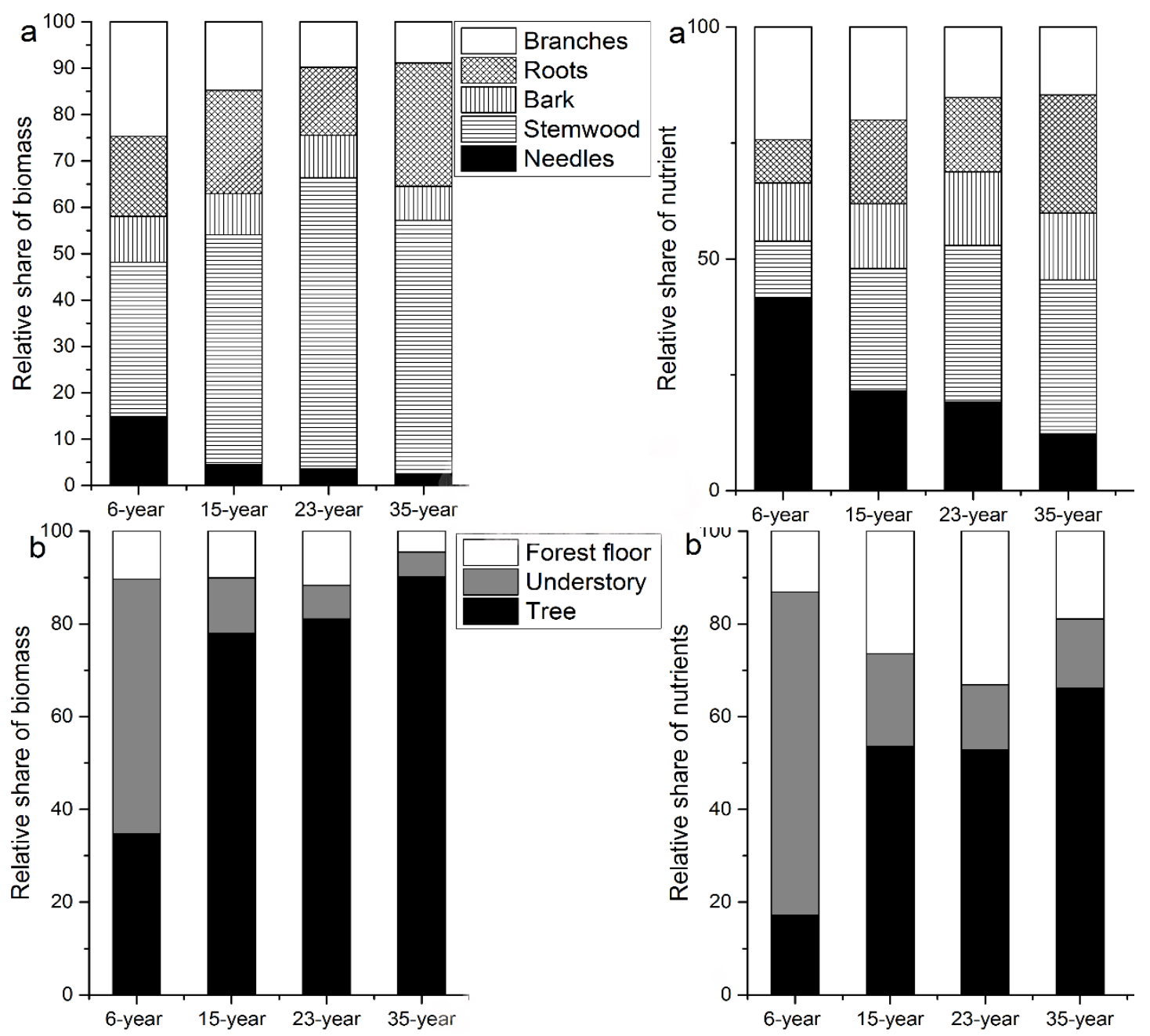

Figure 3. Partitioning of tree components (a) and the tree, understory, and forest floor (b) biomass and nutrients in four ages of larch plantations.

The understory biomass in all examined stands was rich in species and accounted for at least 5.6\% of the total vegetation biomass in this study. Conversely, understory vegetation developed poorly and inadequately, with an average coverage of 30\% due to the high coverage of larch trees (90\%). Hence, the understory biomass accounted for less than $3 \%$ of the total vegetation biomass in the intensive larch stand [28]. This difference may be due to the influence of different thinning treatments, which could rapidly increase understory cover and abundance due to increased light availability [51,52]. Most new species were established within the first year following thinning $[53,54]$. Thinning was conducted in the 15- and 23-year-old larch plantations in 2008, and the understory biomass was investigated in 2009. Nutrient stocks in the understory were three times greater than those in trees in the 6-year-old larch plantation, indicating that nutrient competition may exist between trees and the understory prior to crown canopy closure. This result was consistent with the findings by Alifragis et al. [36], who reported that nutrient accumulation was considerably higher than that in the understory vegetation for 
younger stands, as compared to Aleppo pines. Furthermore, nutrient uptake by trees mainly resulted from understory litter decomposition in the first three years after crown closure [55].

The forest floor stands out as a central compartment in the ecosystem that functions in nutrient cycling [56]. Biomass and nutrient stocks in the forest floor peaked in the 23-year-old stand and then decreased in this study. This pattern was consistent with the findings by Peichl and Arain [31], who examined forest floor biomass in age-sequence temperate pine plantations. These changes are partly due to thinning treatments and changes in light access within the environment. The initial increase was mainly due to greater litter inputs and lower litterfall decomposition rates, while the later decline was attributed to stimulated decomposition on the forest floor and reduced litter inputs following thinning $[49,57]$. Furthermore, greater amounts of nutrients released into the soil led to higher available soil nutrient concentrations at the 35-year-old plantation, indicating that successional thinning in larch plantations promoted understory vegetation growth and accelerated litterfall decomposition [43], which could improve soil properties [58].

Overall, our results regarding nutrient stock allocation to different compartments emphasized the importance of soil in the larch ecosystem. A decline in productivity due to soil nutrient losses was unlikely at the investigated sites, as even WTH-mediated nutrient removal in the 35-year-old stand was a small percentage of the total nutrient stocks in the larch ecosystem. This is in accordance with many similar studies [38,59]. Ma et al. [19] reported that the net annual loss of soil nutrients due to harvesting a 24-year-old Chinese fir plantation was a very small percentage of the total soil nutrient capital. Net nutrient removal due to the harvest of a 70-year-old spruce-fir stand combined with hydrologic losses did not exceed $5 \%$ of the total site capital [60]. Stark [61] stated that it would require 28,000 years of clear-cutting on a 70-year rotation to exhaust the total nutrients in a larch/Douglas-Fir, and nutrient losses may cause little harm in relatively rich soils. Although these studies examined different kinds of tree species and site types (Table 5), N quantities in trees (220-372 $\mathrm{kg} \mathrm{ha}^{-1}$ ) accounted for a similar percentage, $3.5 \%-6.2 \%$, of that in soil stocks $\left(4188-7720 \mathrm{~kg} \mathrm{ha}^{-1}\right)$. Therefore, regarding nutrient quantities, sites with similar soil conditions to those found in these studies should be able to support sustainable development and long-term productivity [62]. Fortunately, many larch plantations were planted on relatively fertile soil, such as dark-brown forest soil in China. Based on the results obtained in this study and related literature (Table 5), it can conclude that nutrient losses via harvesting in sites have little effect on soil nutrient pools.

Table 5. Comparison with biomass and nutrient allocation to several species of tree forests.

\begin{tabular}{|c|c|c|c|c|c|c|c|c|c|}
\hline \multirow{2}{*}{ Species } & \multirow{2}{*}{ Location } & \multirow{2}{*}{ Layer } & \multirow{2}{*}{$\begin{array}{c}\text { Biomass } \\
\left(\mathrm{Mg} \mathrm{ha}^{-1}\right)\end{array}$} & \multicolumn{6}{|c|}{ Nutrient Stocks (kg ha-1) } \\
\hline & & & & $\mathbf{N}$ & $\mathbf{P}$ & $\mathbf{K}$ & $\mathrm{Ca}$ & $\mathrm{Mg}$ & References \\
\hline \multirow{2}{*}{ Larch } & $34^{\circ} 13^{\prime} \mathrm{N}$ & soil & - & 7720 & 1830 & 85,560 & 37,340 & 38,400 & This study \\
\hline & $105^{\circ} 48^{\prime} \mathrm{E}$ & tree & 116.5 & 278.22 & 65.01 & 170.98 & 460.9 & 66.35 & \\
\hline \multirow[t]{2}{*}{ Eucalyptus } & $33^{\circ} 24^{\prime} \mathrm{S}$ & soil & - & 4188.2 & $30.4(\mathrm{AP})$ & 1063.6 & 1289.5 & 595.7 & {$[50]$} \\
\hline & $105^{\circ} 00^{\prime} \mathrm{E}$ & tree & 149.8 & 220.6 & 18.15 & 215.4 & 687.3 & 115.3 & \\
\hline \multirow[t]{2}{*}{ Chinese fir } & $25.8^{\circ} \mathrm{N}$ & soil & - & 6740 & 1770 & 125,000 & 21,900 & 21,900 & [19] \\
\hline & $117^{\circ} 8 \mathrm{E}$ & tree & 142.3 & 295.3 & 33.72 & 234.4 & 281.1 & 59.85 & \\
\hline \multirow[t]{2}{*}{ Spruce-fir } & $45^{\circ} 57^{\prime} \mathrm{N}$ & soil & - & 5833 & 2697 & 10,001 & 10,332 & 36,450 & [60] \\
\hline & $69^{\circ} 19^{\prime} \mathrm{W}$ & tree & - & 376 & 54 & 224 & 494 & 52 & \\
\hline \multirow[t]{2}{*}{ Mixed oak } & - & soil & - & - & - & - & - & - & [34] \\
\hline & & tree & 149.3 & 230 & 18 & 40 & 480 & 38 & \\
\hline
\end{tabular}

\subsection{Nutrient Exports through Harvesting}

Estimates of nutrient losses due to differing harvesting scenarios are shown in Table 6. The data showed that nutrient losses via thinning with WTH was 2.5 times higher than that with $\mathrm{SOH}$ in the 15-year-old plantation. The most nutrient-rich components (i.e., needles and branches) should remain at sites to avoid nutrient losses after thinning [63], particularly during early stand thinning [64]. Compared to $\mathrm{WTH}, \mathrm{SOH}$ could obtain $71.9 \%$ and $62.0 \%$ of the total tree biomass in the $23-$ and 35 -year-old stands, respectively, while removing only $49.7 \%$ and $47.6 \%$ of the total tree nutrients. 
This result is in accordance with several other studies, which reported that WTH increases nutrient removal by 2 - to 3 -fold in pine, spruce, birch, and larch stands compared to $\mathrm{SOH}[27,45]$. Nutrient concentrations, especially $\mathrm{Ca}$, were generally higher in bark than in stemwood [1,65], but applying the debarking treatment is not recommended for three major reasons. Firstly, compared to the needles and forest floor, low nutrient concentrations in bark make decomposition difficult. Therefore, bark may take much more time to completely decompose and release nutrients into the soil [46]. Secondly, the main purpose of stem debarking is to primarily reduce Ca loss $[16,66]$. However, Ca concentration was clearly lower in bark than in the forest floor, in which much Ca must have accumulated. For instance, Ca stocks were only $63.3 \mathrm{~kg} \mathrm{ha}^{-1}$ in the bark and $130.1 \mathrm{~kg} \mathrm{ha}^{-1}$ in the forest floor of the 35 -year-old stand, respectively. Most importantly, the debarking treatment would be highly uneconomical with current harvesting systems $[16,67]$. Of course, a higher Ca concentration in bark was also widely observed [37]. Therefore, debarking application may be reconsidered for Ca-limited sites.

Table 6. Removal of biomass and nutrients from the 15-, 23-, and 35-year-old stands, under different harvesting scenarios.

\begin{tabular}{|c|c|c|c|c|c|c|c|c|c|c|c|}
\hline Ages & Scenarios & & \multicolumn{2}{|c|}{ Biomass } & \multicolumn{6}{|c|}{ Nutrient Stocks $\left(\mathrm{kg} \mathrm{ha}^{-1}\right)$} & $\begin{array}{c}\text { Percentage } \\
(\%)\end{array}$ \\
\hline 15-year & & WTH & 19.4 & 100 & 57.4 & 16.0 & 47.4 & 63.8 & 9.5 & 194.1 & 100 \\
\hline 23-year & Clear-cutting & $\mathrm{SOH}$ & 61.5 & 71.9 & 60.5 & 21.1 & 60.4 & 238.7 & 21.3 & 402 & 49.7 \\
\hline \multirow[t]{2}{*}{ 35-year } & Clear-cutting & $\mathrm{SOH}$ & 72.2 & 62.0 & 54.7 & 24.6 & 58.4 & 323.6 & 35 & 496.3 & 47.6 \\
\hline & & WTH & 116.5 & 100 & 278.2 & 64.9 & 171 & 460.9 & 66.3 & 1041.3 & 100 \\
\hline
\end{tabular}

$\mathrm{SOH}=$ stem-only harvest, $\mathrm{WTH}=$ whole-tree harvest.

When aiming to maximize biomass harvesting for bioenergy, root lifting is a better alternative than logging residue removal without considering harvesting costs $[22,64,67]$. Our data indicate that roots account for a large proportion of tree biomass, particularly in the 35-year-old stand, but root nutrient concentrations were significantly lower than that of needles, branches, understory, and forest floor. In general, ensuring an appropriate harvest rotation length in northern forest ecosystems, especially conifer-dominated forests, could be a simple way to enable forest recovery from slight to moderate effects caused by previous intensive harvests and to maintain forest ecosystem services $[63,68]$. This study indicated that prolonging the harvest rotation from 23- to 35-year-old stands would be a feasible management practice for improving nutrient use efficiency (except for $\mathrm{Ca}$ ) and recovering available soil nutrient concentrations.

\section{Conclusions}

Our study provides detailed information on nutrient allocation ( $, \mathrm{P}, \mathrm{K}, \mathrm{Ca}$, and $\mathrm{Mg}$ ) among different compartments (the trees, understory, forest floor, and soil) of the larch ecosystem. Stems contained $40.4 \%-49.7 \%$ of total tree nutrients in the 15 - to 35 -year-old stands. Meanwhile, the trees accounted for $53.6 \%-66.2 \%$ of the total vegetation and forest floor nutrients in all stands, except in the 6-year-old stands. Moreover, compared to the trees, understory, and forest floor, soil nutrient pools accounted for about $93 \%-99 \%$ of total nutrients in the larch ecosystem. Therefore, regarding nutrient quantities, nutrient losses via harvesting, even by WTH, have little effect on the soil nutrient pools. In addition, extending the crop cycle would be a feasible management practice for improving nutrient use efficiency (except for $\mathrm{Ca}$ ) and recovering the available soil nutrient concentrations. Keeping the nutrient-rich residues on-site would reduce nutrient losses, whether thinning 15- or harvesting 23- and 35-year-old stands. When aiming to maximize biomass harvesting and minimizing nutrient losses, root lifting is a better alternative than logging residue removal. Overall, rational thinning treatments, 
such as successive thinning conducted on the 35-year-old plantation, can increase the understory cover, promote litter decomposition, and allow available soil nutrients to recover.

Author Contributions: H.W., analyzed the data and drafted the manuscript; D.C., performed the experiments; X.S., conceived and designed the experiments. All the authors contributed to manuscript revision.

Funding: This work was supported by the Key Program of National Natural Science Foundation of China (No. 31430017); and the National key Research and Development Program of China (No.2017YFD0600401).

Conflicts of Interest: The authors declare no conflict of interest.

\section{References}

1. Hytönen, J. Biomass, nutrient content and energy yield of short-rotation hybrid aspen (P. tremula $\times P$. tremuloides) coppice. For. Ecol. Manag. 2018, 413, 21-31. [CrossRef]

2. Picchio, R.; Verani, S.; Sperandio, G.; Spina, R.; Marchi, E. Stump grinding on a poplar plantation: Working time, productivity, and economic and energetic inputs. Ecol. Eng. 2012, 40, 117-120. [CrossRef]

3. Brandtberg, P.O.; Olsson, B.A. Changes in the effects of whole-tree harvesting on soil chemistry during 10 years of stand development. For. Ecol. Manag. 2012, 277, 150-162.4. [CrossRef]

4. Kaarakka, L.; Tamminen, P.; Saarsalmi, A.; Kukkola, M.; Helmisaari, H.S.; Burton, A.J. Effects of repeated whole-tree harvesting on soil properties and tree growth in a Norway spruce (Picea abies (L.) Karst.) stand. For. Ecol. Manag. 2014, 313, 180-187. [CrossRef]

5. Mushinski, R.M.; Gentry, T.J.; Dorosky, R.J.; Boutton, T.W. Forest harvest intensity and soil depth alter inorganic nitrogen pool sizes and ammonia oxidizer community composition. Soil Biol. Biochem. 2017, 112, 216-227. [CrossRef]

6. Nieminen, T.M.; Finér, L.; Laiho, R.; Ukonmaanaho, L.; Laurén, A.; Sarkkola, S.; Nieminen, M. Should harvest residues be left on site in peatland forests to decrease the risk of potassium depletion? For. Ecol. Manag. 2016, 374, 136-145.

7. Nieminen, M.; Sarkkola, S.; Laurén, A. Impacts of forest harvesting on nutrient, sediment and dissolved organic carbon exports from drained peatlands: A literature review, synthesis and suggestions for the future. For. Ecol. Manag. 2017, 392, 13-20. [CrossRef]

8. Wall, A. Effect of removal of logging residue on nutrient leaching and nutrient pools in the soil after clearcutting in a Norway spruce stand. For. Ecol. Manag. 2008, 256, 1372-1383. [CrossRef]

9. Tamminen, P.; Saarsalmi, A.; Smolander, A.; Kukkola, M.; Helmisaari, H.S. Effects of logging residue harvest in thinnings on amounts of soil carbon and nutrients in Scots pine and Norway spruce stands. For. Ecol. Manag. 2012, 263, 31-38. [CrossRef]

10. Hornbeck, J.W.; Smith, C.T.; Martin, Q.W.; Tritton, L.M.; Pierce, R.S. Effects of intensive harvesting on nutrient capitals of three forest types in New England. For. Ecol. Manag. 1990, 30, 55-64. [CrossRef]

11. Mendham, D.S.; O'Connell, A.M.; Grove, T.S.; Rance, S.J. Residue management effects on soil carbon and nutrient contents and growth of second rotation eucalypts. For. Ecol. Manag. 2003, 181, 357-372. [CrossRef]

12. Phillips, T.; Watmough, S.A. A nutrient budget for a selection harvest: Implications for long-term sustainability. Can. J. For. Res. 2012, 42, 2064-2077. [CrossRef]

13. Gómez-García, E.; Diéguez-Aranda, U.; Cunha, M.; Rodríguez-Soalleiro, R. Comparison of harvest-related removal of aboveground biomass, carbon and nutrients in pedunculate oak stands and in fast-growing tree stands in NW Spain. For. Ecol. Manag. 2016, 365, 119-127. [CrossRef]

14. Duchesne, L.; Houle, D. Impact of nutrient removal through harvesting on the sustainability of the boreal forest. Ecol. Appl. 2008, 18, 1642-1651. [CrossRef] [PubMed]

15. Menegale, M.L.C.; Rocha, J.H.T.; Harrison, R.; Goncalves, J.L.d.M.; Almeida, R.F.; Goncalves, J.L.d.M.; Piccolo, M.d.C.; Hubner, A.; Arthur Junior, J.C.; De Vicente Ferraz, A.; et al. Effect of timber harvest intensities and fertilizer application on stocks of soil C, N, P, and S. Forests 2016, 7, 319. [CrossRef]

16. Pyttel, P.L.; Köhn, M.; Bauhus, J. Effects of different harvesting intensities on the macro nutrient pools in aged oak coppice forests. For. Ecol. Manag. 2015, 349, 94-105. [CrossRef]

17. McMahon, D.E.; Vergütz, L.; Valadares, S.V.; da Silva, I.R.; Jackson, R.B. Soil nutrient stocks are maintained over multiple rotations in Brazilian Eucalyptus plantations. For. Ecol. Manag. 2019, 448, 364-375. [CrossRef] 
18. Premer, M.I.; Froese, R.E.; Vance, E.D. Whole-tree harvest and residue recovery in commercial aspen: Implications to forest growth and soil productivity across a rotation. For. Ecol. Manag. 2019, 447, 130-138. [CrossRef]

19. Ma, X.; Heal, K.V.; Liu, A.; Jarvis, P.G. Nutrient cycling and distribution in different-aged plantations of Chinese fir in southern China. For. Ecol. Manag. 2007, 243, 61-74. [CrossRef]

20. Jang, W.; Keyes, C.R.; Page-Dumroese, D.S. Long-term effects on distribution of forest biomass following different harvesting levels in the northern Rocky Mountains. For. Ecol. Manag. 2015, 358, 281-290. [CrossRef]

21. Helmisaari, H.S.; Hanssen, K.H.; Jacobson, S.; Kukkola, M.; Luiro, J.; Saarsalmi, A.; Tamminen, P.; Tveite, B. Logging residue removal after thinning in Nordic boreal forests: Long-term impact on tree growth. For. Ecol. Manag. 2011, 261, 1919-1927. [CrossRef]

22. Merilä, P.; Mustajärvi, K.; Helmisaari, H.S.; Hilli, S.; Lindroos, A.J.; Nieminen, T.M.; Nöjd, P.; Rautio, P.; Salemaa, M.; Ukonmaanaho, L. Above- and below-ground N stocks in coniferous boreal forests in Finland: Implications for sustainability of more intensive biomass utilization. For. Ecol. Manag. 2014, 311, 17-28. [CrossRef]

23. Gower, S.T.; Richards, J.H. Larches: Deciduous Conifers in an Evergreen World: In their harsh environments, these unique conifers support a net carbon gain similar to evergreens. Bioscience 1990, 40, 818-826. [CrossRef]

24. Zhu, J.; Yang, K.; Yan, Q.; Liu, Z.; Yu, L.; Wang, H. Feasibility of implementing thinning in even-aged Larix olgensis plantations to develop uneven-aged larch-broadleaved mixed forests. J. For. Res. 2010, 15, 71-80. [CrossRef]

25. Yan, T.; Lü, X.T.; Zhu, J.J.; Yang, K.; Yu, L.Z.; Gao, T. Changes in nitrogen and phosphorus cycling suggest a transition to phosphorus limitation with the stand development of larch plantations. Plant Soil 2018, 422, 385-396. [CrossRef]

26. Wang, W.; Wang, H.; Zu, Y. Temporal changes in SOM, N, P, K, and their stoichiometric ratios during reforestation in China and interactions with soil depths: Importance of deep-layer soil and management implications. For. Ecol. Manag. 2014, 325, 8-17. [CrossRef]

27. Yang, K.; Yu, L.; Zhang, J.; Zhu, J.; Yan, T. Nutrient removal under different harvesting scenarios for larch plantations in northeast China: Implications for nutrient conservation and management. For. Ecol. Manag. 2017, 400, 150-158.

28. Liu, S. Nitrogen cycling and dynamic analysis of man made larch forest ecosystem. Plant Soil 1995, 168-169, 391-397. [CrossRef]

29. Zhao, Q.; Liu, X.Y.; Zeng, D.H. Aboveground biomass and nutrient allocation in an age-sequence of Larix olgensis plantations. J. For. Res. 2011, 22, 71-76. [CrossRef]

30. Zhang, W.; Lu, Z.; Yang, K.; Zhu, J. Impacts of conversion from secondary forests to larch plantations on the structure and function of microbial communities. Appl. Soil Ecol. 2017, 111, 73-83. [CrossRef]

31. Peichl, M.; Arain, M.A. Above- and belowground ecosystem biomass and carbon pools in an age-sequence of temperate pine plantation forests. Agric. For. Meteorol. 2006, 140, 51-63. [CrossRef]

32. Ponette, Q.; Ranger, J.; Ottorini, J.M.; Ulrich, E. Aboveground biomass and nutrient content of five Douglas-fir stands in France. For. Ecol. Manag. 2001, 142, 109-127. [CrossRef]

33. Turner, J.; Lambert, M.J. Analysis of nutrient depletion in a radiata pine plantation. For. Ecol. Manag. 2011, 262, 1327-1336. [CrossRef]

34. Johnson, D.W.; Trettin, C.C.; Todd, D.E. Changes in forest floor and soil nutrients in a mixed oak forest 33 years after stem only and whole-tree harvest. For. Ecol. Manag. 2016, 361, 56-68. [CrossRef]

35. Santos, F.M.; Chaer, G.M.; Diniz, A.R.; de Carvalho Balieiro, F. Nutrient cycling over five years of mixed-species plantations of Eucalyptus and Acacia on a sandy tropical soil. For. Ecol. Manag. 2017, 384, 110-121. [CrossRef]

36. Alifragis, D.; Smiris, P.; Maris, F.; Kavvadias, V.; Konstantinidou, E.; Stamou, N. The effect of stand age on the accumulation of nutrients in the aboveground components of an Aleppo pine ecosystem. For. Ecol. Manag. 2001, 141, 259-269. [CrossRef]

37. Peri, P.L.; Gargaglione, V.; Pastur, G.M. Dynamics of above- and below-ground biomass and nutrient accumulation in an age sequence of Nothofagus antarctica forest of Southern Patagonia. For. Ecol. Manag. 2006, 233, 85-99. [CrossRef]

38. Zhou, L.; Shalom, A.D.D.; Wu, P.; He, Z.; Liu, C.; Ma, X. Biomass production, nutrient cycling and distribution in age-sequence Chinese fir (Cunninghamia lanceolate) plantations in subtropical China. J. For. Res. 2016, 27, 357-368. [CrossRef] 
39. Turner, J.; Lambert, M.; Turner, S. Long term carbon and nutrient dynamics within two small radiata pine catchments. For. Ecol. Manag. 2017, 389, 1-14. [CrossRef]

40. Chang, Y.; Li, N.; Wang, W.; Liu, X.; Du, F.; Yao, D. Nutrients resorption and stoichiometry characteristics of different-aged plantations of Larix kaempferi in the Qinling Mountains, central China. PLoS ONE 2017, 12, 1-15. [CrossRef]

41. Peri, P.L.; Gargaglione, V.; Pastur, G.M. Above- and belowground nutrients storage and biomass accumulation in marginal Nothofagus antarctica forests in Southern Patagonia. For. Ecol. Manag. 2008, 255, 2502-2511. [CrossRef]

42. Ares, A.; Neill, A.R.; Puettmann, K.J. Understory abundance, species diversity and functional attribute response to thinning in coniferous stands. For. Ecol. Manag. 2010, 260, 1104-1113. [CrossRef]

43. Son, Y.; Gower, S.T. Nitrogen and phosphorus distribution for five plantation species in southwestern Wisconsin. For. Ecol. Manag. 1992, 53, 175-193. [CrossRef]

44. Caldeira, D.R.M.; Gonçalves, J.L.M.; Leite, F.P.; Brandani, C.B.; Brunet, D.; Moreira, M.Z.; Bouillet, J.-P.; Paula, R.R.; Tardy, F.; Voigtlaender, M.; et al. Nitrogen cycling in monospecific and mixed-species plantations of Acacia mangium and Eucalyptus at 4 sites in Brazil. For. Ecol. Manag. 2019, 436, 56-67.

45. Palviainen, M.; Finér, L. Estimation of nutrient removals in stem-only and whole-tree harvesting of Scots pine, Norway spruce, and birch stands with generalized nutrient equations. Eur. J. For. Res. 2012, 131, 945-964. [CrossRef]

46. Hernández, J.; del Pino, A.; Salvo, L.; Arrarte, G. Nutrient export and harvest residue decomposition patterns of a Eucalyptus dunnii Maiden plantation in temperate climate of Uruguay. For. Ecol. Manag. 2009, 258, 92-99. [CrossRef]

47. Bravo-Oviedo, A.; Ruiz-Peinado, R.; Onrubia, R.; del Río, M. Thinning alters the early-decomposition rate and nutrient immobilization-release pattern of foliar litter in Mediterranean oak-pine mixed stands. For. Ecol. Manag. 2017, 391, 309-320. [CrossRef]

48. Schumacher, M.V.; Rodríguez-Soalleiro, R.; de Oliveira Ramos, L.O.; Viera, M.; Bonacina, D.M. Biomass and nutrient allocation to aboveground components in fertilized Eucalyptus saligna and E. urograndis plantations. New For. 2017, 48, 445-462.

49. Qiao, Y.; Miao, S.; Silva, L.C.R.; Horwath, W.R. Understory species regulate litter decomposition and accumulation of $\mathrm{C}$ and $\mathrm{N}$ in forest soils: A long-term dual-isotope experiment. For. Ecol. Manag. 2014, 329, 318-327. [CrossRef]

50. Turner, J.; Lambert, M. Pattern of carbon and nutrient cycling in a small Eucalyptus forest catchment, NSW. For. Ecol. Manag. 2016, 372, 258-268. [CrossRef]

51. Larson, A.J.; Goodburn, J.M.; Belote, R.T.; Page-Dumroese, D.S.; Schaedel, M.S.; Affleck, D.L.R. Early forest thinning changes aboveground carbon distribution among pools, but not total amount. For. Ecol. Manag. 2017, 389, 187-198.

52. Nunes, A.; Oliveira, G.; Cabral, M.S.; Branquinho, C.; Correia, O. Beneficial effect of pine thinning in mixed plantations through changes in the understory functional composition. Ecol. Eng. 2014, 70, 387-396. [CrossRef]

53. Trentini, C.P.; Campanello, P.I.; Villagra, M.; Ritter, L.; Ares, A.; Goldstein, G. Thinning of loblolly pine plantations in subtropical Argentina: Impact on microclimate and understory vegetation. For. Ecol. Manag. 2017, 384, 236-247. [CrossRef]

54. Dagley, C.M.; Berrill, J.P.; Leonard, L.P.; Kim, Y.G. Restoration thinning enhances growth and diversity in mixed redwood/Douglas-fir stands in northern California, U.S.A. Restor. Ecol. 2018, 26, 1170-1179. [CrossRef]

55. Carneiro, M.; Serrão, V.; Fabião, A.; Madeira, M.; Balsemão, I.; Hilário, L. Does harvest residue management influence biomass and nutrient accumulation in understory vegetation of Eucalyptus globulus Labill. plantations in a Mediterranean environment? For. Ecol. Manag. 2009, 257, 527-535. [CrossRef]

56. Van Cleemput, O.; Muhindo, D.; Boeckx, P.; Cizungu, L.; Staelens, J.; Walangululu, J.; Huygens, D. Litterfall and leaf litter decomposition in a central African tropical mountain forest and Eucalyptus plantation. For. Ecol. Manag. 2014, 326, 109-116.

57. Seiwa, K.; Etoh, Y.; Hisita, M.; Masaka, K.; Imaji, A.; Ueno, N.; Hasegawa, Y.; Konno, M.; Kanno, H.; Kimura, M. Roles of thinning intensity in hardwood recruitment and diversity in a conifer, Criptomeria japonica plantation: A 5-year demographic study. For. Ecol. Manag. 2012, 269, 177-187. [CrossRef] 
58. Dang, P.; Gao, Y.; Liu, J.; Yu, S.; Zhao, Z. Effects of thinning intensity on understory vegetation and soil microbial communities of a mature Chinese pine plantation in the Loess Plateau. Sci. Total Environ. 2018, 630, 171-180. [CrossRef]

59. Piirainen, S.; Finér, L.; Starr, M. Changes in forest floor and mineral soil carbon and nitrogen stocks in a boreal forest after clear-cutting and mechanical site preparation. Eur. J. Soil Sci. 2015, 66, 735-743. [CrossRef]

60. Briggs, R.D.; Hornbeck, J.W.; Smith, C.T.; Lemin, R.C.; McCormack, M.L. Long-term effects of forest management on nutrient cycling in spruce-fir forests. For. Ecol. Manag. 2000, 138, 285-299. [CrossRef]

61. Stark, N.M. Nutrient Losses from Timber Harvesting in a Larch/Douglas-Fir Forest; USDA Forest Service Research Pap. INT-231; Intermountain Forest and Range Experiment Station: Ogden, UT, USA, 1979.

62. O'Connell, A.M.; Sankaran, K.V.; Grove, T.S.; Mendham, D.S.; Rance, S.J.; Kumaraswamy, S. Harvest residue effects on soil organic matter, nutrients and microbial biomass in eucalypt plantations in Kerala, India. For. Ecol. Manag. 2014, 328, 140-149.

63. Achat, D.L.; Deleuze, C.; Landmann, G.; Pousse, N.; Ranger, J.; Augusto, L. Quantifying consequences of removing harvesting residues on forest soils and tree growth - A meta-analysis. For. Ecol. Manag. 2015, 348, 124-141. [CrossRef]

64. Nieminen, M.; Laiho, R.; Sarkkola, S.; Penttilä, T. Whole-tree, stem-only, and stump harvesting impacts on site nutrient capital of a Norway spruce-dominated peatland forest. Eur. J. For. Res. 2016, 135, 531-538. [CrossRef]

65. Turner, J.; Lambert, M.J. Nutrient cycling in age sequences of two Eucalyptus plantation species. For. Ecol. Manag. 2008, 255, 1701-1712. [CrossRef]

66. Hopmans, P.; Stewart, H.T.L.; Flinn, D.W. Impacts of harvesting on nutrients in a eucalypt ecosystem in southeastern Australia. For. Ecol. Manag. 1993, 59, 29-51. [CrossRef]

67. Picchio, R.; Sirna, A.; Spina, R.; Sperandio, G.; Verani, S. Mechanized harvesting of eucalypt coppicefor biomass production using high mechanization level. Croat. J. For. Eng. 2012, 33, 15-24.

68. Hume, A.M.; Chen, H.Y.H.; Taylor, A.R. Intensive forest harvesting increases susceptibility of northern forest soils to carbon, nitrogen and phosphorus loss. J. Appl. Ecol. 2018, 55, 246-255. [CrossRef]

(C) 2019 by the authors. Licensee MDPI, Basel, Switzerland. This article is an open access article distributed under the terms and conditions of the Creative Commons Attribution (CC BY) license (http://creativecommons.org/licenses/by/4.0/). 